\title{
Bioerosive structures formed by Miocene rock-boring bivalves in Hokkaido, Japan
}

\author{
Akihiko Suzuki ${ }^{1}$ and Nobuhide Hiranaka ${ }^{2}$
}

\begin{abstract}
Akihiko Suzuki and Nobuhide Hiranaka (2008) Bioerosive structures formed by Miocene rock-boring bivalves in Hokkaido, Japan. Bull. Geol. Surv. Japan, vol. 59, (7/8), 385-395, 9 figs.
\end{abstract}

\begin{abstract}
Fossilized rock-boring bivalves and associated borings in the Miocene Sankebetsu Formation in northern Hokkaido, Japan, are useful for reconstructing paleoenvironmental changes. The sediments are typical of shallow-marine facies in Hokkaido, and are rich in rock-boring bivalve traces. The Miocene host formation (Sankebetsu Formation, 23-19 Ma) unconformably overlies an earlier Eocene formation (Sakasagawa Formation). The inferred paleoenvironmental changes associated with deposition of the Miocene Sankebetsu Formation at the study locality started with development of a wave-cut bench of stiff mud or soft rock that was extensively bored by the rock-boring bivalve Platyodon nipponica to form unnamed ichnofossils. The bench was subsequently covered by sediments associated with a transgression and were gradually lithified. A later regression lead to the development of new bench of hard rock that was bored by the rock-boring bivalve Penitella kotakae to form the boring ichnofossil identified as Gastrochaenolites turbinatus. Finally, the new bench was covered by sediments during a major transgression, forming a shoreface environment characterized by storm-generated shell beds. The analysis of bioerosion on marine rocky surfaces is a useful tool for interpreting geological episodes such as relative oscillations of sea level, erosion/sedimentation rates, and the intensity of physical disturbance.
\end{abstract}

Key words: ancient rocky-shore, rock-boring bivalve, Miocene, boring ichnofossil, Sankebetsu Formation, Hokkaido

\section{Introduction}

Rock-boring bivalves have been studied by many researches (Bromley, 1992; Taylor and Wilson, 2003), and fossilized borings and bivalve fauna are common in sediments dating from the Paleozoic to the present. The borings formed by these bivalves are commonly infilled with overlying sediment and preserved in situ. The autochthonous occurrence of these fossils makes these features useful as paleoecological and paleoenvironmental indicators (Itoigawa, 1963; Dewey and Keady, 1992; Suzuki and Hikida, 2005).

Rock-boring bivalve fossils have been employed in the Japanese Islands for many years to determine the depositional facies and environments of ancient rocky shores (e.g., Uozumi and Fujie, 1956; Itoigawa, 1963; Masuda, 1968). Miocene sediments from the shallowmarine facies of Hokkaido, northern Japan, are rich in rock-boring bivalve fossils (Uozumi and Fujie, 1956; Itoigawa, 1963; Kanno and Matsuno, 1960; Kanno et al., 1968; Noda, 1992; Suzuki et al., 2006). However, although these rock-boring bivalve fossils have been described in terms of systematic paleontology, the fossils have yet to be fully studied from paleoecological and taphonomic perspectives.
In the present study, we characterize the stratigraphic horizon bearing the rock-boring bivalve fossils and describe the modes of fossil bivalve and boring occurrences. We then infer the paleoenvironmental changes of the ancient rocky shore, based on the paleoecology and ichnology of the rock-boring bivalves and associated borings.

\section{Geological setting}

The Miocene boring bivalve fossils in the present study is exposed in the Haboro area of northern Hokkaido, northern Japan (Fig. 1). The Tertiary strata widely distributed in this area (Fig. 2) are divided into the Haboro, Sakasagawa, Sankebetsu, Chikubetsu, Kotambetsu, Chepotusnai, Embetsu and Mochikubetsu Formations, in ascending order (Matsuno and Kino, 1960; Kurita et al., 1992; Hoyanagi, 1992; Hoyanagi et al., 1994).

The Sakasagawa Formation (Hoyanagi et al., 1994) unconformably overlies the Haboro Formation and attains a maximum thickness of $200 \mathrm{~m}$. The formation has been reported to be Late Eocene in age on the basis of microbiostratigraphic data (Kurita et al., 1992; Hoyanagi et al., 1994), and is composed of muddy fine-

${ }^{1}$ Department of Earth Science, Sapporo Campus, Hokkaido University of Education, Sapporo 002-8502, Japan

${ }^{2}$ Sapporo Touun Senior High School, Sapporo 006-0026, Japan 


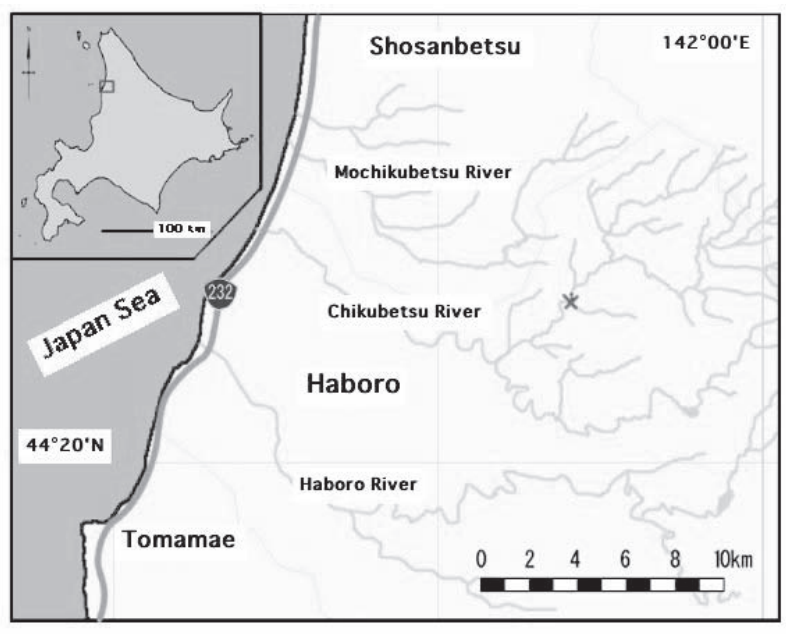

Fig. 1 Map showing the fossil locality with rock-boring bivalves. The Akebono locality is $15 \mathrm{~km}$ upstream of the Chikubetsu-gawa River, Haboro Town, Hokkaido, Japan. The large-scale map is represented by the rectangle indicated on the inset small scale map.

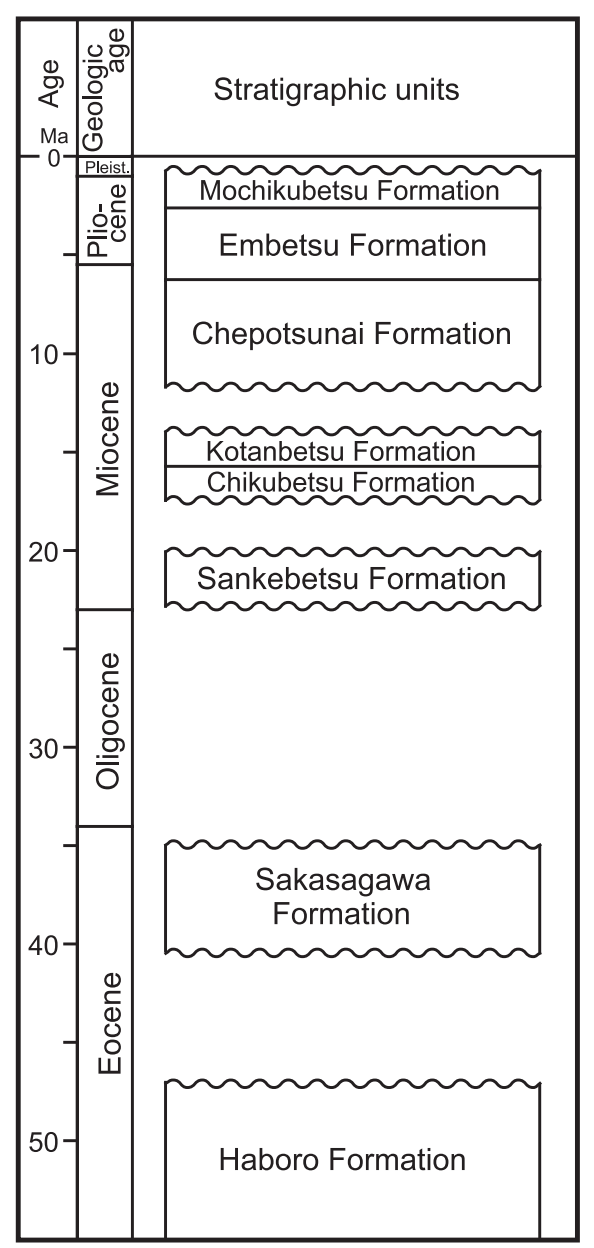

Fig. 2 Tertiary stratigraphy in the Haboro area, Hokkaido. grained sandstone without distinct sedimentary structures, suggesting a sandy shelf environment (Hoyanagi et al., 1994). The faunal composition of the molluscan fossils present in the Sakasagawa Formation resembles that of the Poronai Fauna (Noda, 1992).

The Sakasagawa Formation is unconformably overlain by the Sankebetsu Formation, which reaches a maximum thickness of $300 \mathrm{~m}$. The Sankebetsu Formation is divided into a lower sandstone part and an upper mudstone part. The lower part is composed of massive, finegrained sandstone with a basal conglomerate, while the upper part is mainly composed of massive tuffaceous mudstone. The formation is considered to be early Miocene in age, based on dinoflagellate biostratigraphy (Kurita et al., 1992), which is supported by a K-Ar date in the Sankebetsu Horizon (Hoyanagi and Matsui, 1985). The chronostratigraphic data therefore suggest a gap of approximately 10 Ma between the Sakasagawa and Sankebetsu formations (Fig. 2). The stratigraphy of the Sankebetsu Formation can be interpreted as a transgressive-regressive succession (Hoyanagi et al., 1994). Molluscan fossils in the formation form the Sankebetsu faunal assemblage, which is rich in cold-water elements that originated in the northern Pacific region (Noda, 1992; Ogasawara, 1994; Suzuki, 2000).

\section{Modes of occurrence of borings and causative bivalves}

At the fossil locality in Akebono, the Sankebetsu Formation is exposed along an upper stream of the Chikubetsu River (Fig. 1). The Sankebetsu Formation unconformably overlies the Sakasagawa Formation with a sharp erosional contact at the outcrop (Fig. 3). The Sakasagawa Formation is composed of dark-grey, muddy, fine-grained sandstone with scattered shells and calcareous nodules, consistent with a sandy shelf paleoenvironment (Hoyanagi et al., 1994). The overlying Sankebetsu Formation is composed of blue-grey medium-grained sandstone with shell beds and typical hummocky cross-stratification suggestive of a shoreface paleoenvironment (Hoyanagi et al., 1994). The sequence boundary between the formations is interpreted as a ravinement surface produced by shoreface erosion associated with transgression (Hoyanagi et al., 1994).

Many borer shells and borings are observed on the erosion surface between the two formations (Fig. 4). Large boring fossils (Type I borings) cut sharply and perpendicularly into the fine-grained sandstone, with Platyodon shells preserved in situ, conjoined and aggregated in place. Small boring fossils (Type II borings) also cut sharply and perpendicularly into the finegrained sandstone, with Penitella shells preserved in situ, conjoined and aggregated in place. 


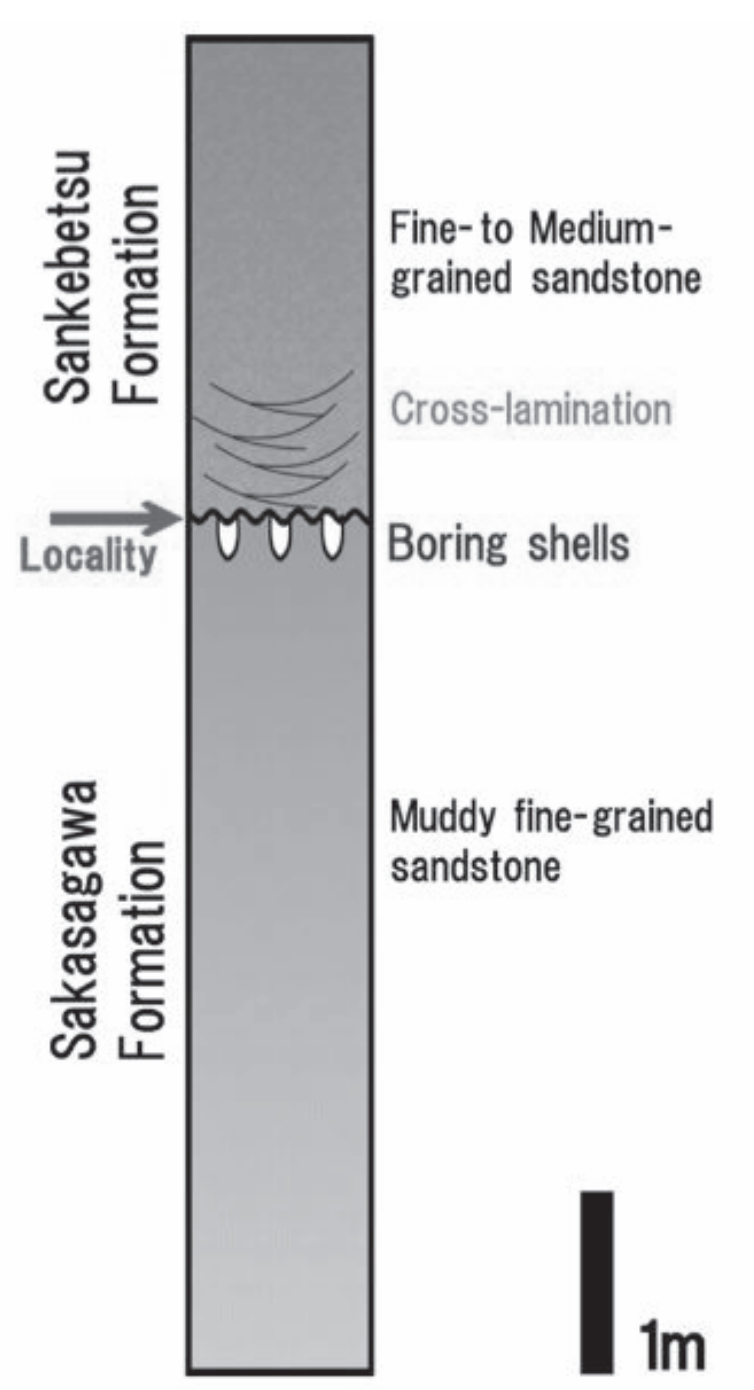

Fig. 3 Columnar section of Tertiary formations at the locality, showing the fossil horizon.

\section{Remarks on fossil rock-boring bivalves}

Family Myidae

Genus Platyodon (Conrad, 1837)

Platyodon nipponica (Uozumi and Fujie, 1956)

(Fig. 5)

Remarks: Many specimens were examined, some of which were deformed or partly fractured. Shells display some variation in outline, from elongate to somewhat shortened. The living American species Platyodon cancellata (Conrad, 1837; Yonge, 1951; Adegoke, 1967) has a lower, more elongate and less inflated shell than the species in the present study. $P$. cf. nipponica, reported by O'Hara and Nemoto (1984) from the Goyasu Formation in the Joban coal field, may be identical to the present species.

Occurrence: Sankebetsu and Chikubetsu Formations in Hokkaido, Japan.
Family Pholadidae

Genus Penitella (Valenciennes, 1846)

Penitella kotakae (Kanno and Matsuno, 1960)

(Fig. 6)

Remarks: Many specimens were examined. Shells display some variation in outline, from elongate to shortened. The present species resembles $P$. cf. kotakae from the Goyasu Formation as reported by O'Hara and Nemoto (1984). The present species is related to the modern Japanese species Penitella kamakurensis (Yokoyama, 1922), although with a distinctly narrower and slender posterior area separating the anterior via a radial groove.

Occurrence: Sankebetsu, Chikubetsu, Jugosenzawa and Horomui Formations in Hokkaido, Japan. Ilyin Suite in western Kamchatka, Russia (Gladenkov et al., 1984).

\section{Ichnological features of bivalve borings}

Type I borings were found in the Sankebetsu Formation at Akebono (Fig. 7). These borings, created by Platyodon nipponica, are large with a long clubshaped outline. The longitudinal axes are nearly straight, extending for 10-15 cm, and are arranged at angles of $70-80^{\circ}$ with respect to the basal plane of the formation. Cross-sections are elliptical in the upper part, oval-shaped in the middle part, and heart-shaped in the lower portion. The borings are rather narrow in the upper to middle parts, with diameters of 3-4 cm, below which the borings quickly expand to $5-6 \mathrm{~cm}$ in diameter. The basal end is bluntly pointed and wedge-shape in vertical section. In general, the upper parts are not well preserved, likely due to erosion after burial of the trace fossils. The borings are filled with fine- to mediumgrained sandstone.

The morphological characteristics of the Type I borings were illustrated by Uozumi and Fujie (1956) based on examples found in the Chikubetsu Formation of the Haboro area. This type of boring has not been described in other localities and is re-examined here from an ichnological perspective.

Type II borings were also found in the Sankebetsu Formation at Akebono (Fig. 8). These borings, formed by Penitella kotakae, are small (3-5 cm in length) with a flask-shaped outline, indicative of the Gastrochaenolites ichnogenus (Leymerie, 1842). These Gastrochaenolites are circular in cross-section through the full depth of the boring. The aperture is narrow, with the boring enlarging conically with depth until finally tapering to form a rounded base. The longitudinal axes are slightly bent half-way along the boring length, but are oriented generally perpendicular to the basal plane of the formation. The cross-section has a relatively uniform diameter of $2-3 \mathrm{~cm}$ along the length of the boring, but is slightly constricted in the uppermost portion and slightly expanded at the basal end, which is regularly rounded. These 

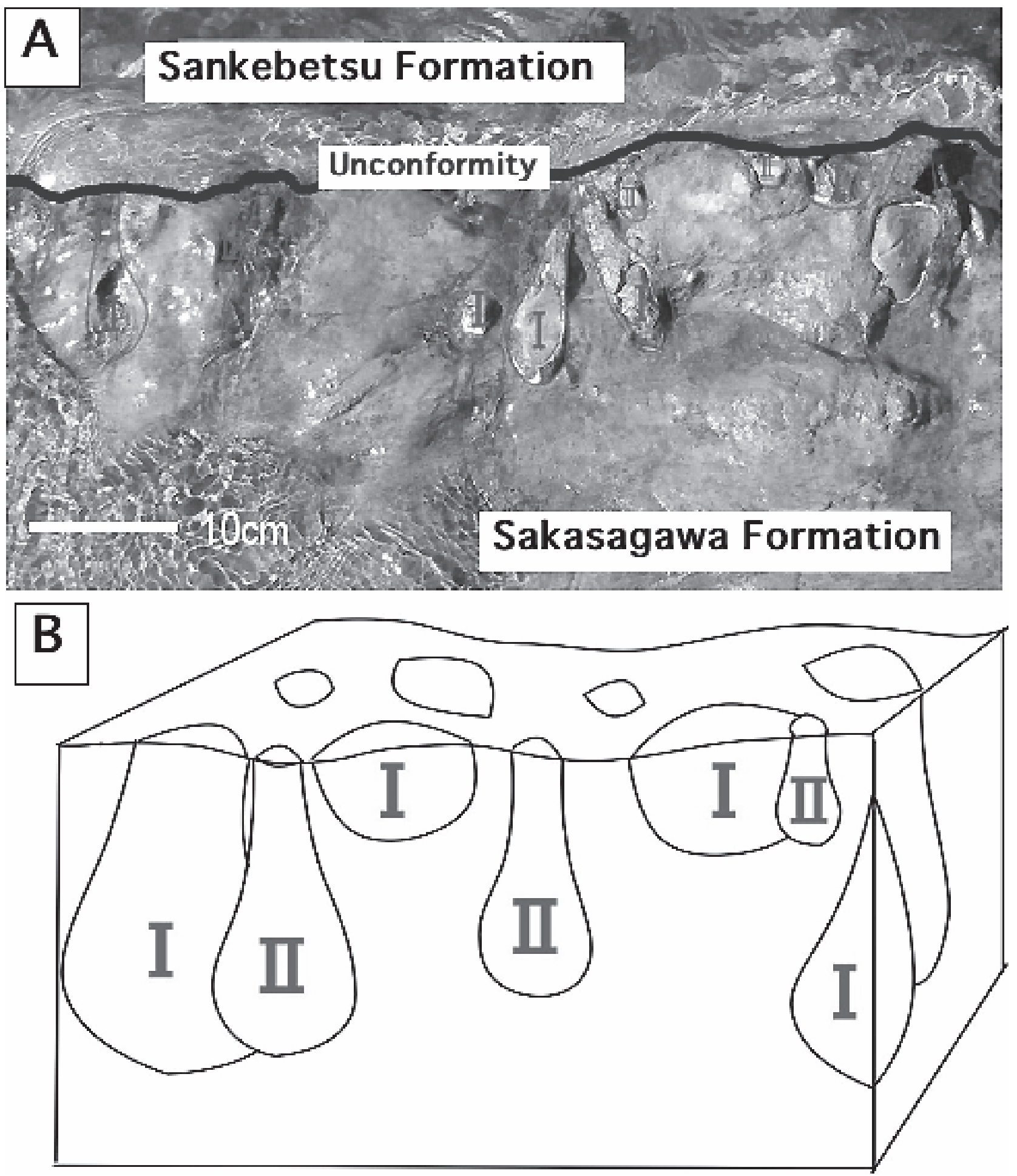

Fig. 4 A. Modes of occurrence of rock-boring bivalves and their borings at the unconformity surface between the Sakasagawa and Sankebetsu formations at Akebono. B. Idealized modes of occurrence of boring ichnofossils at the unconformity. Not to scale. 

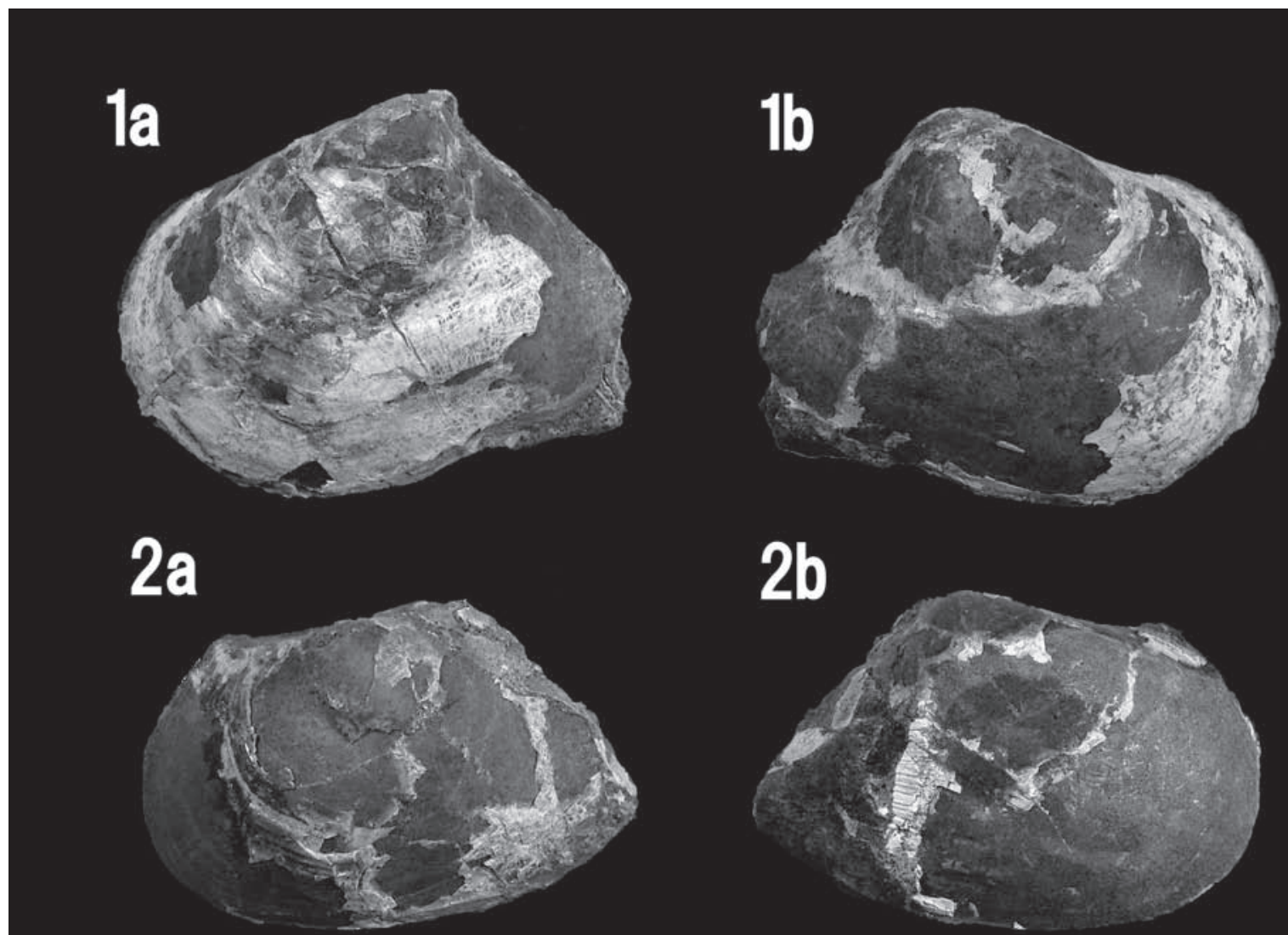

\section{3a}

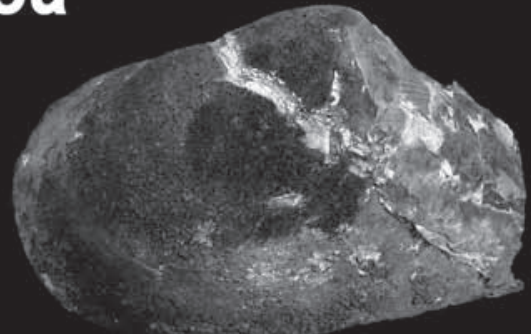

$4 \mathrm{a}$

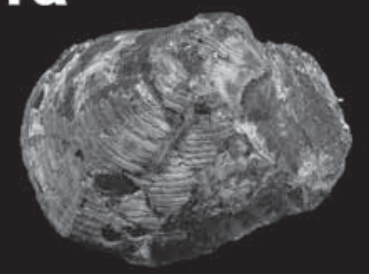

$4 b$

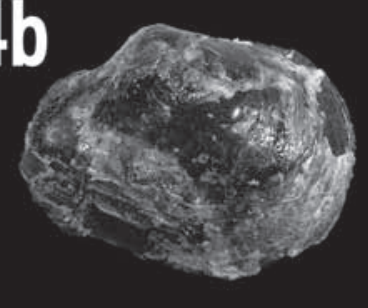

$5 \mathrm{a}$

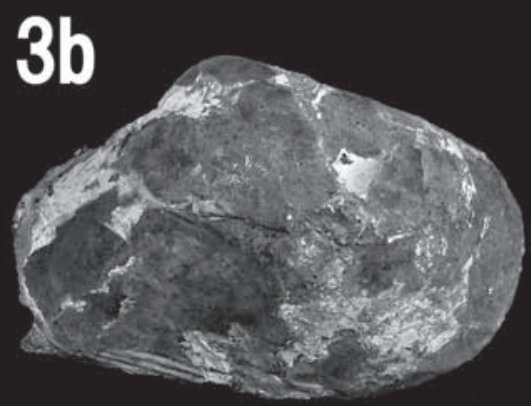

$6 \mathrm{a}$

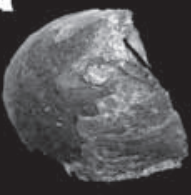

$6 b$
$5 b$
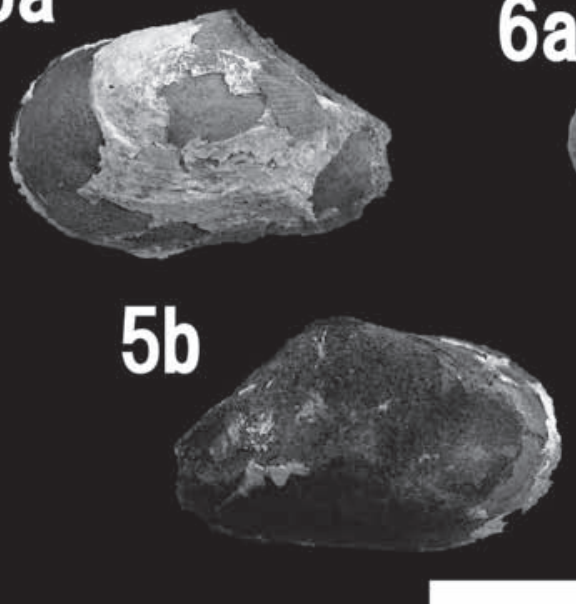

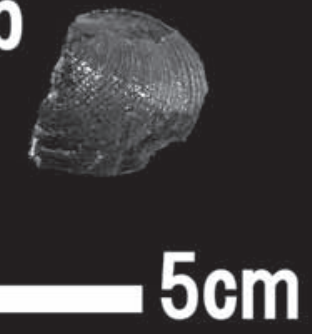

Fig. 5 The rock-boring bivalve, Platyodon nipponica, from the Sankebetsu Formation. 1. 6. Platyodon nipponica Uozumi and Fujie. 


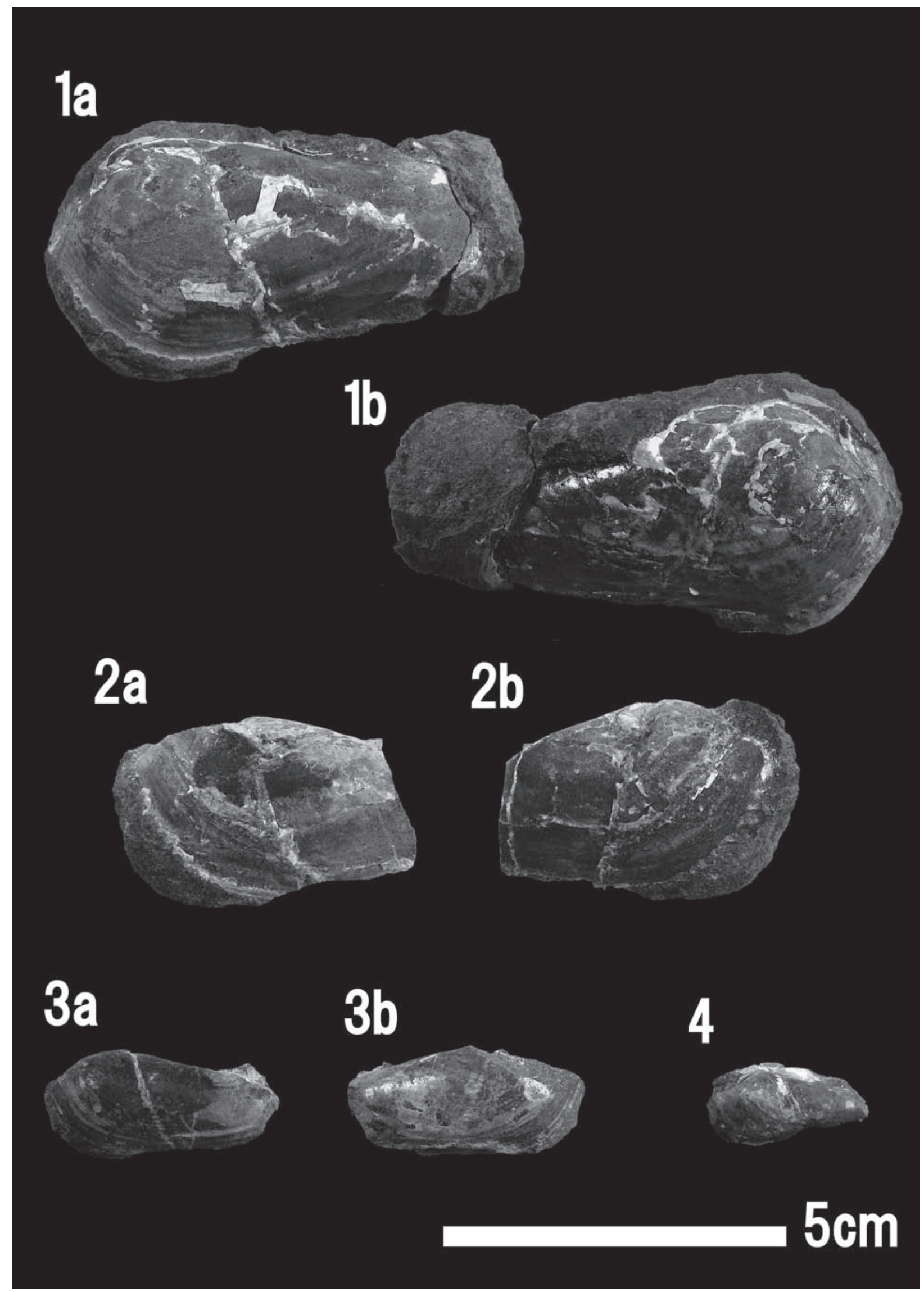

Fig. 6 The rock-boring bivalve, Penitella kotakae, from the Sankebetsu Formation. 1. 4. Penitella kotakae Kanno and Matsuno. 


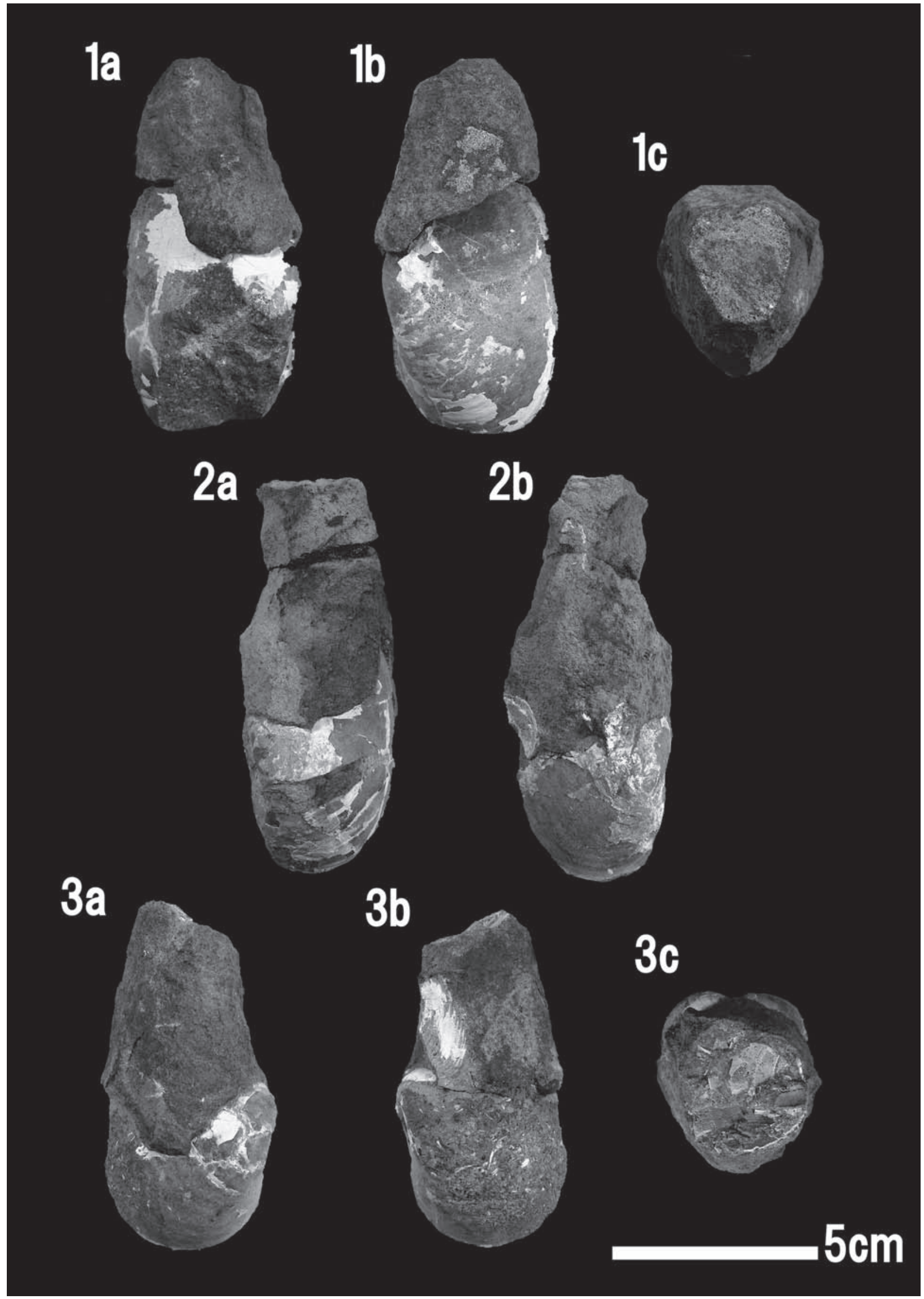

Fig. 7 Club-shaped boring ichnofossil, created by Platyodon nipponica, from the Sankebetsu Formation. 1. 3. Boring ichnofossils, created by Platyodon nipponica. 


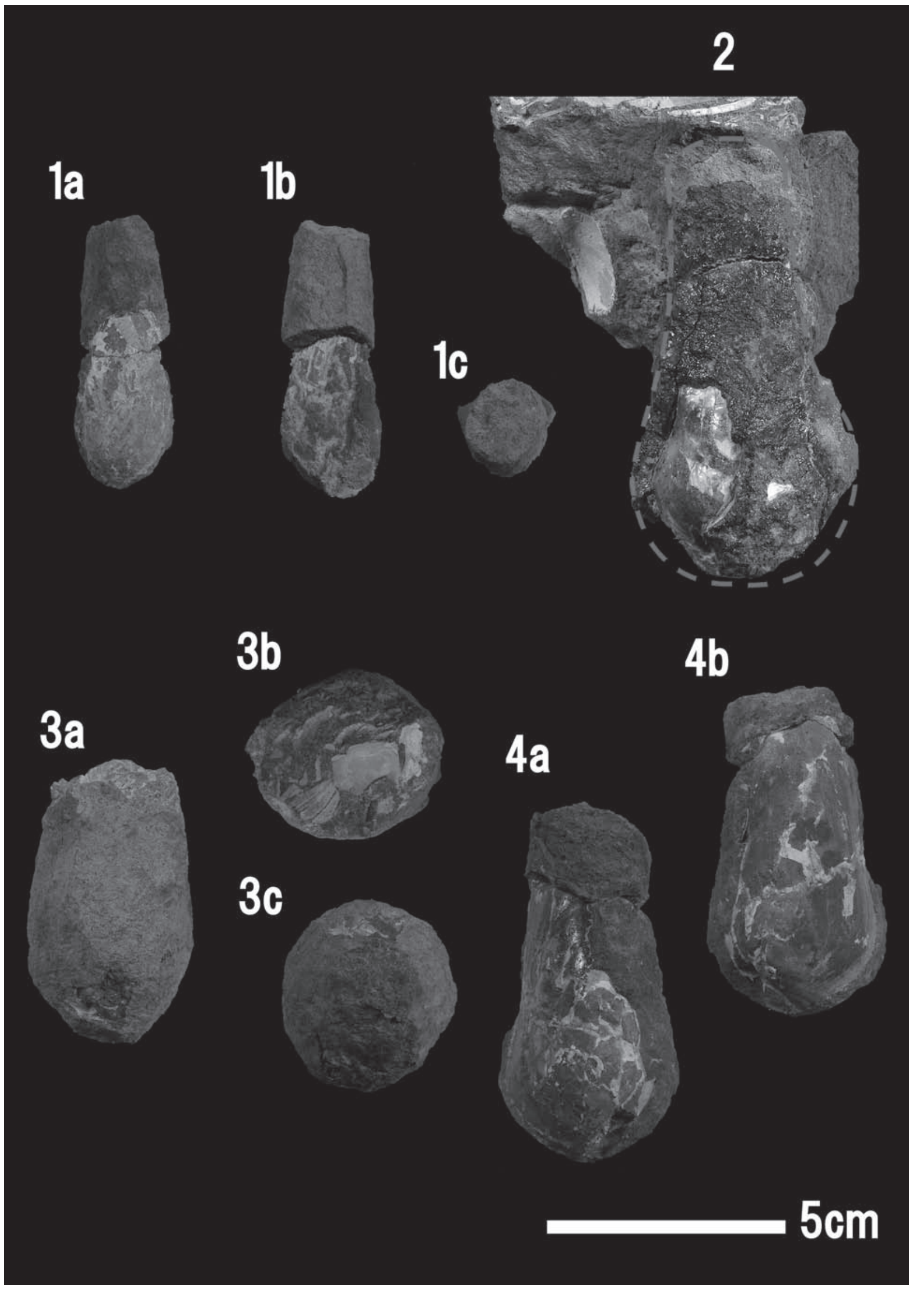

Fig. 8 The ichnofossil, Gastrochaenolites turbinatus, created by Penitella kotakae, from the Sankebetsu Formation. 1. 4. Gastrochaenolites turbinatus Kelly and Bromley. 
trace boring fossils are filled with medium- to coarsegrained sandstone, which is lithologically similar to the superposed sediments.

The morphological characteristics of Type II borings was also illustrated by Uozumi and Fujie (1956) based on examples from the Chikubetsu Formation along the Haborogawa River in the Haboro area. This type was assigned to Gastrochaenolites turbinatus by Kelly and Bromley (1984).

\section{Discussion}

Based on our field observations and paleoecological analysis, paleoenvironmental changes at the Akebono locality may be divided into four stages (Fig. 9), as follows:

Stage 1: After deposition of the Sakasagana Formation, the exposed surface consolidated into stiff mud or very soft rock, which was subsequently eroded by a marine transgression to form an intertidal wave-cut bench. The boring bivalve Platyodon nipponica worked this bench aggressively, forming the club-shaped borings with associated bivalve shells. The intertidal bench was colonized by $P$. nipponica, producing extensive unnamed trace boring fossils during a period of non-deposition. The club- shaped borings were in-filled with local sediment and thus preserved in situ.

Stage 2: A subsequent regression lowered sea level and exposed the previously intertidal surface to terrestrial weathering, allowing the sharp erosion of sediments to form a rock outcrop.

Stage 3: The boring bivalve Penitella kotakae colonized a new intertidal bench during a later period of non-deposition, to form the boring traces identified as Gastrochaenolites turbinatus. The rock-surface colonization by bivalves may correlate with the Entobia ichnofacies (Bromley, 1992, 1994).

Stage 4: A resumption of sedimentary activity caused these flask-shaped borings to become in-filled with local sediment and thus to be preserved in situ along with the associated bivalves. A rapid transgression is indicated, during which the wave-cut bench would have transformed into an upper-shoreface sandy bottom associated with a high-energy environment. Such a paleoenvironment is indicated by the presence of many shell-beds rich in open-sea bivalves such as Spisula and Mercenaria, and by the hummocky cross-stratification of the sandy sediments.

In summary, the formation of the Sankebetsu sedimentary sequence started with the development of a

\section{Intetidal zone}

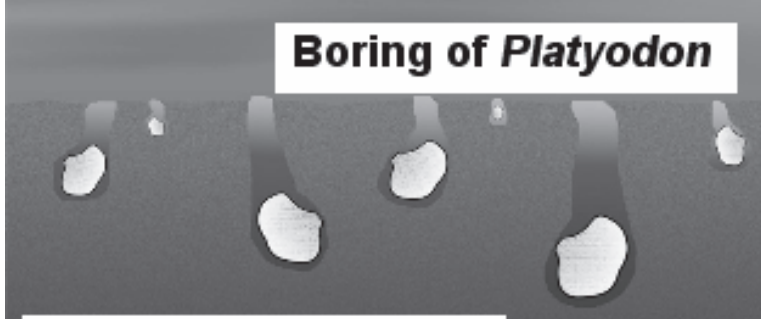

Stiff mud or Soft rock

\section{Regression}

\section{lithification of basement due to lapse of time}

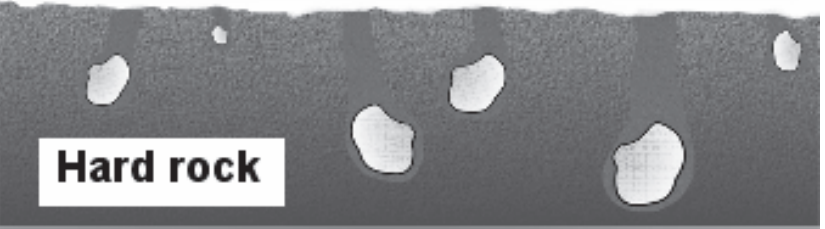

\section{Upper shoreface}

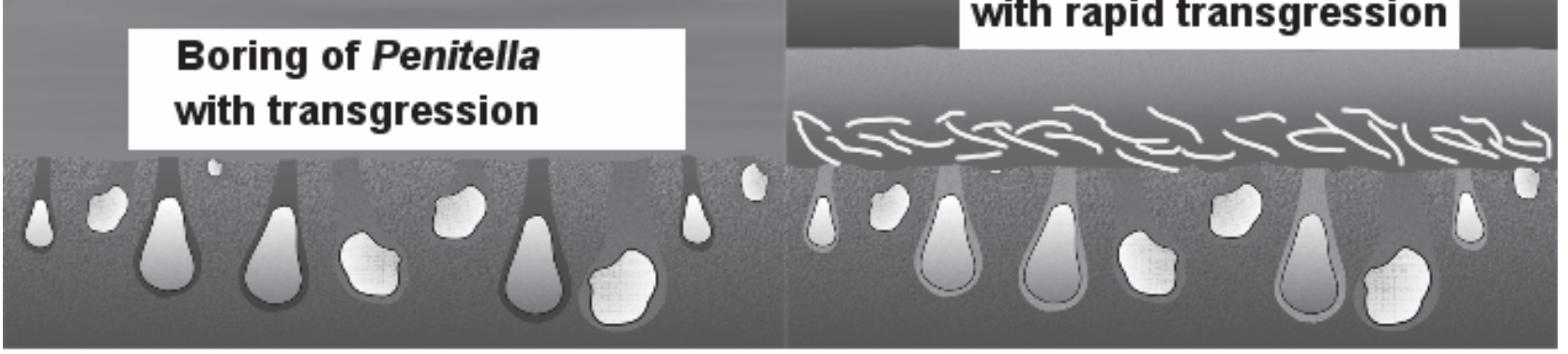

Fig. 9 Schematic diagram showing the paleoenvironmental reconstruction of rock-boring bivalves and their clavate borings from the Sankebetsu Formation. 
wave-cut bench of stiff mud or soft rock that was extensively bored by the rock-boring bivalve Platyodon nipponica to form an unnamed ichnofossil. The bench was then covered with sediments and gradually lithified, followed by the development of a new bench of hard rock that was bored by the rock-boring bivalve Penitella kotakae to form the boring ichnofossil Gastrochaenolites turbinatus. Finally, the bench was again covered with sediments and inundated to form a shoreface environment with storm-generated shell beds during a transgressive cycle. The present analysis of bioerosion on marine rocky surfaces demonstrates that the technique is useful for interpreting geological episodes such as relative oscillations of sea level, erosion/sedimentation rates, and the intensity of physical disturbances.

Acknowledgments: The authors are grateful to Professor Yoshihiro Togo of the Hokkaido University of Education for helpful advice on the manuscript, to Dr. Morio Akamatsu of the Historical Museum of Hokkaido, to Dr. Yoshinori Hikida of the Nakagawa Museum of Natural History for assistance in examining fossil specimens, and to Mr. Daisuke Koshitaka of Sapporo Kaisei Senior High School for field assistance. The authors also would like to Professor Kenshiro Ogasawara, University of Tsukuba, and Dr. Louie Marincovich Jr., California Academy of Science for their constructive reviews and for improving the manuscript. This study was supported by a Grant-in-aid for Scientific Research from the Japan Society for the Promotion of Science (C 17540440).

\section{References}

Adegoke, O. S. (1967) Earliest Tertiary west American species of Platyodon and Penitella. Proc. California Acad. Sci., 4th Ser., 35, 1-22.

Bromley, R. G. (1992) Bioerosion: eating rocks for fun and profit. In Maples, C. G. and West, R. R., eds., Trace Fossils (Short Courses in Paleontology, no. 5), Paleontological Society, Knoxville, Tennessee, 121-129.

Bromley, R. G. (1994) The palaeoecology of bioerosion. In Donovan, S. K. ed., The Palaeobiology of Trace Fossils, John Wiley and Sons, Chichester, 134-154.

Conrad, T. A. (1837) Description of new marine shells from upper California. Jour. Philadelphia Acad. Sci., 7, 227-268.

Dewey, C. P. and Keady, D. M. (1992) On the occurrence of the trace fossil Gastrochanolites and causative bivalve in the Tallahatta Formation (Eocene) of east-central Mississippi. Mississippi Geol., 13, 49-54.

Gladenkov, Yu. B., Gladikova, V. M., Kafanov, A. M., Konova, L.V., Krishtofovich, L.V., Sinelnikova, L. N. and Popov, S.V. (1984) Sea mollusks. In
Menner, V. V. ed., Atlas of fauna and flora of the Neogene sediments of the Far East Tochilnski Key Section of Western Kamchatka (Acad. Sci. USSR, Trans.), 385, 152-250. (in Russian)

Hoyanagi, K. (1992) Sedimentary environments and sequence stratigraphy of the Neogene system in the Haboro area, northern part of the central Hokkaido. Mem. Geol. Soc. Japan, no. 37, 227-238. (in Japanese with English abstract)

Hoyanagi, K. and Matsui, M. (1985) K-Ar age of the Tertiary Sankebetsu Formation in the Haboro region, northern Hokkaido, Japan. Earth Sci., 39, 74-77. (in Japanese with English abstract)

Hoyanagi, K., Fukusawa, H. and Noda, Y. (1994) Sedimentary facies and deposition sequences of the turbidite and shallow marine deposits. Excursion Guidebook, 101st Ann. Meet., Geol. Soc. Japan, Sapporo, 125-137. (in Japanese with English abstract)

Itoigawa, J. (1963) Miocene rock- and wood- boring bivalves and their burrows from the Mizunami Group, central Japan. Jour. Earth Sci., Nagoya Univ., 11, 101-123.

Kanno, S. and Matsuno, K. (1960) Molluscan fauna from the "Chikubetsu Formation", Hokkaido, Japan. Jour. Geol. Soc. Japan, 66, 35-45.

Kaseno, Y. and Matsuura, N. (1964) Fossil boring shells found on the uncomformable surface below the Omma Formation (Pliocene) near Kanazawa City, Japan. Jour. Geol. Soc. Japan, 70, 565-571.

Kanno, S., O'Hara, S. and Kaiteya, K. (1968) The "Asahi fauna" from the Miocene formations developed near the Asahi Coal-mine, Iwamizawa City, Hokkaido. Sci. Rep. Tokyo Kyoiku Daigaku, Sec. C, 10, 1-14.

Kelly, S. R. A. and Bromley, R. G. (1984) Ichnological nomenclature of clavate borings. Palaeontology, 27, 793-807.

Kurita, H., Ichinoseki, T. and Hiramatsu, C. (1992) Geologic age of the Sankebetsu and Haboro Formations, Haboro area, northern Hokkaido. Jour. Geol. Soc. Japan, 98, 259-266. (in Japanese with English abstract)

Leymerie, M. A. (1842) Suite de memoire sur le terrain Cretace du department de l'Aube. Memoir de la Societe Geologique de France, 5, 1-34.

Matsuno, M. and Kino, Y. (1960) Explanatory Text of the Geological Map of Japan, Scale 1:50,000, Chikubetsu-Tanko. Hokkaido Development Agency, 43p. (in Japanese with English abstract)

Masuda, K. (1968) Sand pipes penetrating igneous rocks in the environs of Sendai, Japan. Trans. Proc. Palaeont. Soc. Japan, N. S., no. 72, 351-362.

Noda, Y. (1992) Neogene molluscan faunas from the Haboro coal-field, Hokkaido, Japan. Sci. Rep. Tohoku Univ., 2nd Ser., 62, 1-140. 
Ogasawara, K. (1994) Neogene paleogeography and marine climate of the Japanese Islands based on shallow-marine molluscs. Palaeogeogr., Palaeoclimatol., Palaeoecol., 108, 335-351.

O'Hara, S. and Nemoto, N. (1984) Molluscan fossils from the type Goyasu Formation of the Joban Coalfield. Jour. Coll. Art. Sci., Chiba Univ., Ser. B, 17, 45-61.

Suzuki, A. (2000) Paleoenvironmental significance of Miocene molluscan faunas in Hokkaido, northern Japan. Bull. Ashoro Mus. Paleont., no.1, 57-66. (in Japanese with English abstract)

Suzuki, A. and Hikida, Y. (2005) Boring organisms and hard substrate ichnofacies: examples of rock-boring trace fossils in Hokkaido. Jour. Fossil Res., 38, 811. (in Japanese with English abstract)

Suzuki, A., Hiranaka, N. and Hikida, Y. (2006) Bioerosive structures of Miocene rock-boring bivalves in rocky-shore environments, northern Hokkaido, Japan. Abstracts, 17th International Sedimentological Congress, Fukuoka, Japan, P-277.
Taylor, P. D. and Wilson, M. A. (2003) Palaeoecology and evolution of marine hard substrate communities. Earth-Sci. Reviews, 62, 1-103.

Uozumi S. and Fujie, T. (1956) The sandpipe, created by the pelecypods : Platyodon nipponica $\mathrm{n}$. sp. and Pholadidea (Penitella) kamakurensis (Yokoyama). Jour. Fac. Sci., Hokkaido Univ, Ser. 4, 9, 351-369.

Valenciennes, A. (1846) Atlas de zoologie, mollusques, 4-24. In M. A. Du-Petit-Thouars, Voyage autour du monde sur la fregate La Venus pendant les annes 1836-1839, Paris.

Yokoyama, M. (1922) Fossils from the Upper Musashino of Kazusa and Shimosa. Jour. Coll. Sci., Imp. Univ. Tokyo, 44, 1-200.

Yonge, C. M. (1951) Studies on Pacific coast mollusks. II. Structures and adaptations for rock boring in Platyodon cancellatus (Conrad). Univ. California, Pub. Zoology, 55, 401-408.

Received July, 15, 2008

Accepted September, 16, 2008

\section{北海道の中新世岩石穿孔性二枚貝による生物侵食構造 \\ 鈴木明彦・平中伸英}

要 旨

北海道羽幌地域の中新統三毛別層から産出する岩石穿孔性二枚貝化石とその生痕化石の詳細な検討に基づいて, 古環 境変遷を復元した，調查地点の羽幌地域曙では，始新統逆川層と中新統三毛別層の明瞭な不整合が見られる，大型生痕 化石 Type I は棍棒型をなし，所属未定のグループに相当する。この生痕化石中には，二枚貝化石 Platyodon nipponica が 含まれていた。一方，小型生痕化石 Type II はフラスコ型で, Gastrochaenolite turbinatusに同定される。この生痕化石中 には，二枚貝化石 Penitella kotakae が含まれていた，不整合におけるこのような産状は，いずれも明らかに自生的な産状 を示すものである.

これらは以下のような堆積過程を経て, 形成されたと推察した。初めに軟質岩の波食棚が広くPlatyodon の穿孔を受 け，所属未定の生痕化石を形成した。次に堆積物による充填を経て次第に基盤が固結した。さらに新たな海進が生じて， 硬質岩の波食棚がPenitellaの穿孔を受け，G. turbinatus を形成した。最後に波食棚は，海進の進行に伴って外浜環境へ と移行し，そこではストーム起源による貝化石層が形成されていた。このような穿孔性二枚貝化石による生物侵食構造 の解析は, 海進初期の特徵, 非堆積期間の程度, 古水深の推定等の有効な古環境情報を提供するものである. 